Journal of

Ecology 2002

90, 639-649

\title{
Experimental assessment of Heliconia acuminata growth in a fragmented Amazonian landscape
}

\author{
EMILIO M. BRUNA*††, OLAVO NARDY $\$ \S$, SHARON Y. STRAUSS $\uparrow$ and \\ SUSAN HARRISON $\dagger$ \\ $\dagger$ Center for Population Biology, University of California, 1 Shields Avenue, Davis, CA 95616, USA, \$Biological \\ Dynamics of Forest Fragments Project, PDBFF-INPA, CP 478, Manaus, AM69011-970, Brazil, and \$Departamento \\ de Ecologia, Universidade Estadual Paulista, Rio Claro, SP 13506-900, Brazil
}

\begin{abstract}
Summary
1 Fragmentation severely alters physical conditions in forest understories, but few studies have connected these changes to demographic impacts on forest species using detailed experimental examination at the individual and population levels.

2 Using a 32-month, reciprocal-transplant experiment, we show that individuals of the Amazonian understory herb Heliconia acuminata transplanted into forest fragments lost over $20 \%$ of their vegetative shoots, while those transplanted to continuous forest showed a slight gain. The leaf area of plants in fragments also increased at half the rate it did in continuous forest sites.

3 It appears that the normal dry season stresses to which forest understorey plants are exposed are greatly exacerbated in fragments, causing plants to shed shoots and leaves. 4 The observed shifts in size could help explain why populations in fragments are more skewed towards smaller demographic stage classes than those in continuous forest. These shifts in size structure could also result in reduced abundances of flowering plants, as reproduction in $H$. acuminata is positively correlated with shoot number.

5 Fragmentation-related changes in growth rates resulting from abiotic stress may have significant demographic consequences.
\end{abstract}

Key-words: forest fragmentation, growth rates, Heliconiaceae, root : shoot ratio, understorey plants, water stress

Journal of Ecology (2002) 90, 639-649

\section{Introduction}

The fragmentation of once-continuous habitats is a globally pervasive phenomenon, and understanding how communities respond to fragmentation remains a central area of research in ecology (reviewed in Laurance \& Bierregaard 1997; Harrison \& Bruna 1999). One of its most consistently documented consequences is the dramatic alteration of abiotic conditions in fragments, particularly in forest ecosystems (Kapos 1989; Chen et al. 1992; Gehlhausen et al. 2000). Fragments of rain forest, for example, often have increased air and soil temperatures, reduced relative humidity and reduced soil moisture levels (Kapos 1989; Didham \& Lawton 1999). These changes are thought to drive many of the negative effects of fragmentation, including the local extinction of plants and animals (Leach

*Present address: Department of Wildlife Ecology and Conservation, University of Florida, PO Box 110430, Gainesville, FL 32611, USA. (e-mail brunae@wec.ufl.edu)
\& Givnish 1996; Didham et al. 1998; Carvalho \& Vasconcelos 1999).

Altered environmental conditions could also affect the individuals that survive in fragmented landscapes by influencing their physiological condition (Weishampel et al. 1997; Berwaerts et al. 1998; Sumner et al. 1999; Stratford \& Stouffer 2001). For instance, lizards in Australian rain forest fragments were found to be smaller than those in continuous forest, which was hypothesized to result from increased thermal variance during gestation or perhaps the reduced abundance of temperature-sensitive prey items (Sumner et al. 1999). Similarly, temperature-related reductions in the abundance of insects could account for the lower feather growth rates of insectivorous birds in Amazonian forest fragments although higher evaporative water loss might also be responsible (Stratford \& Stouffer 2001). As no studies have used manipulative experiments to investigate such fragmentation-related differences, it is difficult to determine whether they actually followed fragmentation or merely reflect pre-isolation variation. 


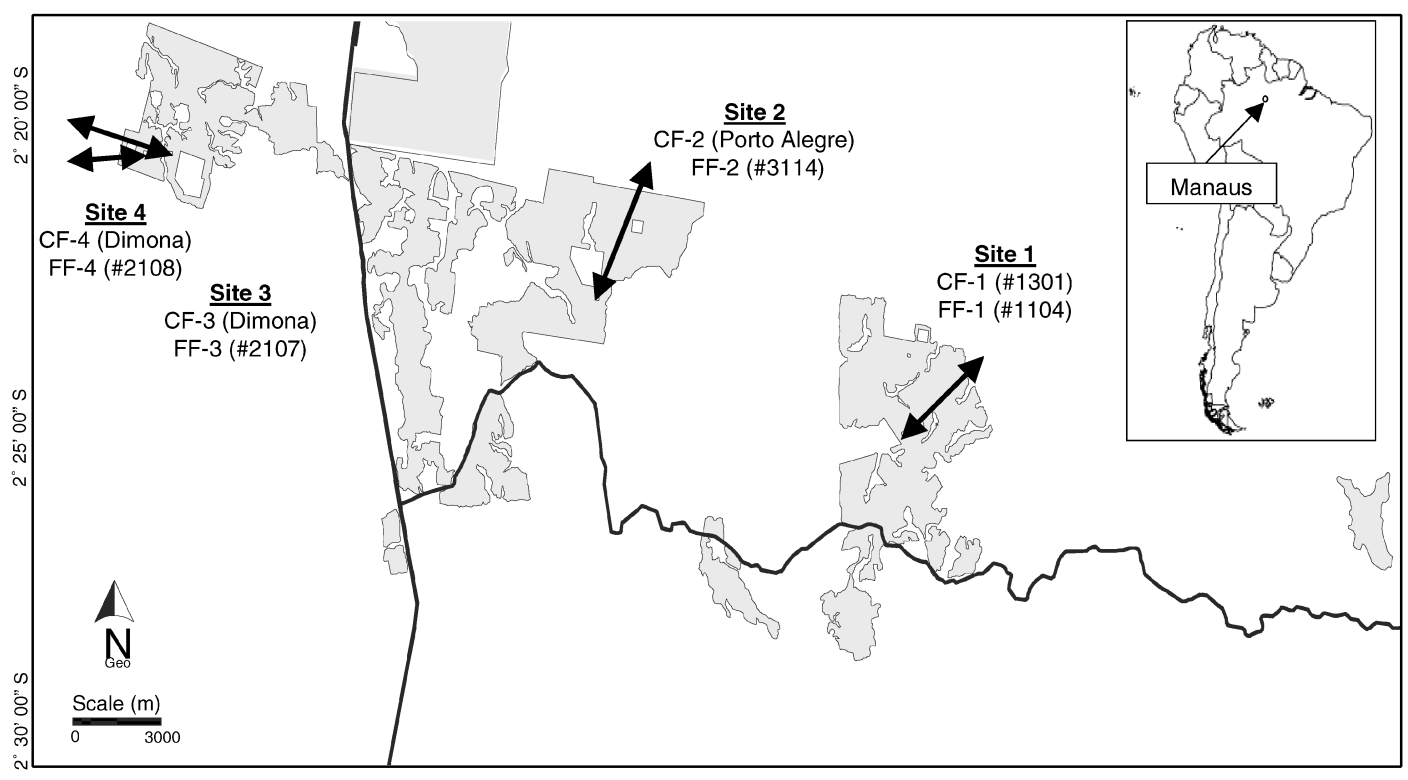

$60^{\circ} 05^{\prime} 00^{\prime \prime} \mathrm{W}$

$60^{\circ} 00^{\prime} 00^{\prime \prime} \mathrm{W}$

$59^{\circ} 55^{\prime} 00^{\prime \prime} \mathrm{W}$

$59^{\circ} 50^{\prime} 00^{\prime \prime} \mathrm{W}$

$59^{\circ} 45^{\prime} 00^{\prime \prime} \mathrm{W}$

Fig. 1 Map of the Biological Dynamics of Forest Fragments Project, indicating sites used in this study. Arrows represent fragments and continuous forest areas between which plants were reciprocally transplanted. Continuous forest areas are white, secondary forest and pastures are grey, dark lines represent roads. Reserve numbers are given in parentheses (Lovejoy et al. 1986), except for continuous forest sites with no BDFFP number, which are referred to by the name of the ranch in which they are located. $\mathrm{FF}=$ forest fragment, $\mathrm{CF}=$ continuous forest.

Furthermore, the long-term demographic consequences of these changes are usually unknown, as the link between the characters measured and individual fitness is unclear.

Understorey plants are ideal systems for experimental investigation of the consequences of fragmentation for individual growth. First, they grow in a layer of the forest characterized by low air and soil temperatures, high relative humidity and limited light, all of which are dramatically altered in tropical forest fragments (Kapos 1989; Camargo \& Kapos 1995; Didham \& Lawton 1999). Secondly, they are readily amenable to landscape-scale experimental manipulations, whereas animals or woody plants frequently are not. Finally, critical life-history transitions in plants, such as survivorship and reproduction, are often size-dependent (Harper 1977; Horvitz \& Schemske 1995), making it possible to infer the demographic consequences of changes in plant size.

Heliconia acuminata is an understorey herb native to central Amazonia and the Guyanas (Berry \& Kress 1991). At Brazil's Biological Dynamics of Forest Fragments Project, where $H$. acuminata is the subject of an ongoing demographic study, populations in small forest fragments are skewed towards smaller size classes than those in continuous forest (Bruna \& Kress 2002). Here we use a 32-month reciprocal transplant experiment to evaluate the prediction that this pattern is due in part to reduced plant growth rates in fragments. We

(C) 2002 British Ecological Society, Journal of Ecology, 90, 639-649 then use the relationship between $H$. acuminata size and reproduction (Bruna 2001; Bruna \& Kress 2002) to infer the demographic consequences of changes in plant size.

\section{Materials and methods}

\section{STUDY SITE AND SPECIES}

This study was conducted at the Biological Dynamics of Forest Fragments Project (BDFFP), located $70 \mathrm{~km}$ north of Manaus, Brazil $\left(2^{\circ} 30^{\prime} \mathrm{S}, 60^{\circ} \mathrm{W}\right.$, Fig. 1$)$. The habitat at the BDFFP is non-flooded lowland rain forest with undulating topography that ranges from 50 to $150 \mathrm{~m}$ in elevation. Mean annual temperature is $26^{\circ} \mathrm{C}$ (range $19-39{ }^{\circ} \mathrm{C}$ ), and annual rainfall ranges from 1900 to $3500 \mathrm{~mm}$. There is a pronounced dry season from June to November

The BDFFP is surrounded by forest that extends for over $200 \mathrm{~km}$ to the north, east and west. In addition to large continuous forest reserves embedded in this expanse, the BDFFP also has several forest fragment reserves isolated in the early 1980 s by the creation of cattle pastures (Lovejoy et al. 1986). Fragments are separated from regenerating secondary growth by a $100-\mathrm{m}$ buffer strip that is repeatedly cleared (BDFFP Records).

Heliconia acuminata (Heliconiaceae) is an understorey perennial monocot found in both the fragment and continuous forest reserves at the BDFFP (Bruna \& Kress 2002). It produces vegetative shoots from a basal rhizome, and each shoot has several large, broad leaves (Berry \& Kress 1991). Reproductive plants also have one or more flowering shoots, each of which has a single infloresence with 20-25 flowers (Bruna \& Kress 2002). Plants usually begin flowering at the start of the rainy season and continue until March; clonal reproduction via underground runners is very limited (E. M. Bruna, personal observation). 
641

Plant growth in rain

forest fragments
A key advantage of the $H$. acuminata system is the lack of major foliar herbivores. Throughout the Neotropics the primary herbivores of Heliconia are Hispine beetles, which cause leaf scarring and readily identifiable perforations but remove little foliar tissue (Strong 1977). In our study sites Hispines primarily feed on inflorescences and developing fruits, and the patterns of herbivory are similar in continuous forest and fragments (E. M. Bruna, unpublished data). Changes in shoot number and leaf area observed during the experiment are therefore not attributable to fragmentationrelated differences in herbivore density.

\section{EXPERIMENTAL DESIGN}

We began by choosing $40 \mathrm{H}$. acuminata individuals in each of four 1-ha fragment reserves and four continuous forest sites (Fig. 1). Most plants initially had two to five vegetative shoots $($ mean $=3.38 \pm 0.04 \mathrm{SE}$ ); these size classes represent $65-67 \%$ of the plants found in permanent demographic plots (Bruna 2001). Half of the selected individuals in each site were chosen at random and immediately transplanted to a paired site of the opposite habitat type (i.e. 'experimental' plants). The other half were removed from the ground and replanted in the same fragment or forest site after an equal amount of time to serve as controls for the effects of travel, transplanting and the possibility of adaptation to local site conditions (i.e. 'control' plants).

Four edge-to-interior transects were established in each fragment, each with an experimental and a control plant transferred to the fragment edge, and at 5, 10, 20 and $40 \mathrm{~m}$ from the edge. Pairs of control and experimental plants had the same number of shoots whenever possible. After transplanting, some of the plants at 40 $m$ were found to be closer to other edges than the one from which their transect originated. We calculated the distance from these plants to the nearest fragment edge and analyses were conducted using these adjusted distances. In continuous forest, sites were 500-2000 m from the nearest primary forest/secondary forest border and transplants were arrayed along four $40 \mathrm{~m}$ transects.

Transplantation occurred during the early part of the 1999 rainy season (7-28 February 1999), at which time we counted the number of vegetative shoots on each plant and calculated its total leaf area using the regression equation:

$\sqrt{\text { Leaf Area }}\left(\mathrm{cm}^{2}\right)=1.72+0.35 \times$ leaf length $(\mathrm{cm})$

( $R^{2}=0.959, P<0.0001$, based on $n=144$ leaf tracings measured with a LI-COR Model 3000 A Leaf Area Meter). Both characters are important indicators of overall plant condition in H. acuminata: total leaf area plays an important role in photosynthesis and the regulation of water loss in many tropical understorey species (Begg 1980), while the number of vegetative shoots is strongly positively correlated with the probability the species will flower (Fig. 2).

We re-measured 7 months after transplanting (18 October to 9 November 1999, following the completion of one rainy and one dry season), 14 months after transplanting (19 April to 14 May 2000, at the end of a second rainy season) and 32 months after transplanting (22-29 October 2001, following three rainy and three dry seasons). All plants were harvested immediately after the final measurement and above- and below-ground portions separated, dried and weighed to the nearest $0.01 \mathrm{~g}$. We used these data to calculate the ratio of root biomass to shoot biomass ( $\mathrm{R}: \mathrm{S}$ ratio) for each plant.

\section{STATISTICAL ANALYSES: GROWTH RATES AND BIOMASS ALLOCATION}

Because shoot number and leaf area are significantly positively correlated in $H$. acuminata $(n=320, \rho=$ $0.402, P<0.0001)$, we used multivariate analysis of covariance (MANCOVA) to compare changes in plant size in forest fragments and continuous forest. The dependent variables were the proportional change in leaf area $\left(\Delta_{\text {la }}\right)$ and shoots $\left(\Delta_{\text {shoots }}\right) 32$ months after transplanting, calculated as:

$\begin{aligned} & \text { proportional } \\ & \text { change in size }(\Delta)\end{aligned}=\frac{\text { final size }- \text { initial size }}{\text { initial size }}$

Proportional change of both shoots and leaf area were square-root-transformed to meet the assumptions of parametric statistics. Source and destination habitat (fragment or continuous forest) and site (1-4) were independent variables, and initial plant size (one to three shoots or four to six shoots) was included as a covariate. Note that while we made repeated measurements of plant size, our experiment was not designed to assess interseason variation in plant growth rates. Therefore although we present data from earlier census dates, only overall growth rates are compared statistically. Analyses were conducted on proportional changes in plant size, but are presented as percentages.

We compared overall $\Delta_{\text {la }}$ and $\Delta_{\text {shoots }}$ in forest fragments at four distances from the fragment edge $(0,5,10$ and $\geq 20 \mathrm{~m}$ ) using multivariate analysis of variance (MANOVA) with site and source habitat type as independent variables. Tukey posthoc tests were used to compare individual means at different distances.

We compared the final $\mathrm{R}: \mathrm{S}$ ratio of plants in continuous forest and forest fragments using analysis of covariance (ANCOVA). The $\mathrm{R}: \mathrm{S}$ ratio at the time of harvesting (log-transformed to correct for non-normality) was used as the dependent variable, with source and destination habitat type and site, as independent variables. As $\mathrm{R}: \mathrm{S}$ ratio in herbaceous plants tends to decrease with increasing plant size (McConnaughay \& Coleman 1999), we included final plant biomass (also log-transformed) as a covariate after confirming
Journal of Ecolo 90, 639-649 
642

E. M. Bruna et al. the negative correlation between $\ln (\mathrm{R}: \mathrm{S}$ ratio $)$ and $\ln$ (biomass) for $H$. acuminata $(n=300, \rho=-0.410$, $P<0.0001)$.

We also used ANCOVA to test for an effect of increasing edge proximity on biomass allocation, as for $\Delta_{\mathrm{la}}$ and $\Delta_{\text {shoots }}$, but comparing the final R : S ratio and with $\ln$ (biomass) as the covariate.

\section{SOIL CHEMISTRY}

To determine if differences in soil nutrients or chemistry could be contributing to the observed results we collected four soil cores from a $5 \times 5 \mathrm{~m}$ area adjacent to a randomly selected point along each transect. These cores were of the uppermost $10 \mathrm{~cm}$ of soil, where the roots of $H$. acuminata are generally found (E.M. Bruna and O. Nardy, personal observation). The four subsamples were then homogenized and bulked into a single sample per transect, yielding a total of four soil samples from each forest fragment or continuous forest site. Total $\mathrm{P}, \mathrm{K}^{+}, \mathrm{Ca}^{2+}, \mathrm{Mg}^{2+}, \mathrm{Al}^{3+}$, total $\mathrm{C}$, total organic material, $\mathrm{Cu}, \mathrm{Fe}, \mathrm{Zn}^{+}, \mathrm{Mn}^{2+}$ and $\mathrm{pH}$ in water were analysed by the Soil Chemistry Laboratory at the Brazilian Agricultural Research Centre in Manaus using standard protocols (EMBRAPA 1997). The average value for the four transects from each site was calculated and median values from continuous forest and forest fragments were compared using Bonferronicorrected Mann-Whitney $U$-tests.

\section{PREDICTED CHANGES IN FLOWERING PLANT} ABUNDANCE

Finally, we used survey data (Bruna 2001) to determine the average values for probability of flowering at a given size (Fig. 2). This, together with the size distributions of experimental plants at the time of transplanting and at the end of the experiment, was used to calculate how many flowering plants would be expected in fragments and continuous forest before and after fragmentation.

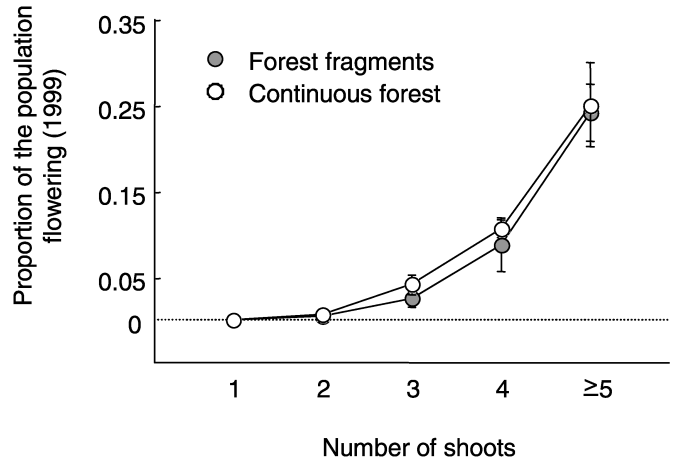

Fig. 2 The mean proportion ( $\pm 1 \mathrm{SE}$ ) of flowering Heliconia acuminata for a given number of shoots. Individuals in four permanent demographic plots in 1-ha fragments (filled circles) and six plots in continuous forest (open circles) were surveyed in 1999 (Bruna 2001). The proportion flowering is significantly positively correlated with shoot number in both habitat types (FF: $n=796, \rho=0.864, P<0.0002$; CF: $n=$ 2384, $\rho=0.904, P<0.0001)$.

We tested for shifts in the initial and final predicted numbers with a $\chi^{2}$ test, in which the predicted numbers in each habitat type at the start of the experiment were used as the expected values and the predicted numbers 32 months later were used as the observed values.

All statistical analyses were conducted with Statview 5.0.1. We present back-transformed values when transformations were necessary.

\section{Results}

There was a significant difference in the growth of $H$. acuminata transplanted to forest fragments and continuous forest ( $P=0.021$, Table 1$)$. After 32 months plants in fragments had $21.5 \%( \pm 4.6 \mathrm{SE})$ fewer shoots than when the experiment began, whereas those in continuous forest were slightly larger $(+1.2 \% \pm 4.5 \mathrm{SE})$ than when originally transplanted (Fig. 3c). Leaf area increased more than twice as much in continuous forest as in forest fragments $\left(\Delta_{\mathrm{la}}: 12.3 \% \pm 7.6 \mathrm{SE}\right.$ vs. $5.5 \% \pm 12$

Table 1 Results of a multivariate analysis of covariance on the proportional change in leaf area and shoot number 32 months after reciprocal transplants between forest fragments and continuous forest

(C) 2002 British Ecological Society, Journal of Ecology, 90, 639-649

\begin{tabular}{|c|c|c|c|c|}
\hline Source of variation & Wilks’ $\Lambda$ & d.f. & $F$ & $P$ \\
\hline Destination habitat & 0.973 & 2,284 & 3.923 & 0.021 \\
\hline Site & 0.831 & 6,568 & 9.198 & $<0.0001$ \\
\hline Source habitat & 0.999 & 2,284 & 0.171 & 0.843 \\
\hline Initial shoot number & 0.953 & 2,284 & 6.971 & 0.001 \\
\hline Destination habitat $\times$ Site & 0.898 & 6,568 & 5.251 & $<0.0001$ \\
\hline Destination habitat $\times$ Source habitat & 0.993 & 2,284 & 1.003 & 0.368 \\
\hline Destination $\times$ Initial shoot number & 0.995 & 2,284 & 0.760 & 0.469 \\
\hline Site $\times$ Source habitat & 0.982 & 6,568 & 0.860 & 0.525 \\
\hline Site $\times$ Initial shoot number & 0.969 & 6,568 & 1.511 & 0.172 \\
\hline Source habitat type $\times$ Initial shoot number & 0.986 & 2,284 & 2.082 & 0.127 \\
\hline Destination habitat $\times$ Site $\times$ Source habitat & 0.986 & 6,568 & 0.693 & 0.656 \\
\hline Destination habitat $\times$ Site $\times$ Initial shoot number & 0.984 & 6,568 & 0.757 & 0.604 \\
\hline Source habitat $\times$ Source $\times$ Initial shoot number & 0.992 & 6,568 & 0.377 & 0.894 \\
\hline Destination $\times$ Source $\times$ Initial shoot number & 0.998 & 2,284 & 0.335 & 0.715 \\
\hline Destination habitat $\times$ Site $\times$ Source habitat $\times$ Initial shoot number & 0.987 & 6,568 & 0.623 & 0.712 \\
\hline
\end{tabular}



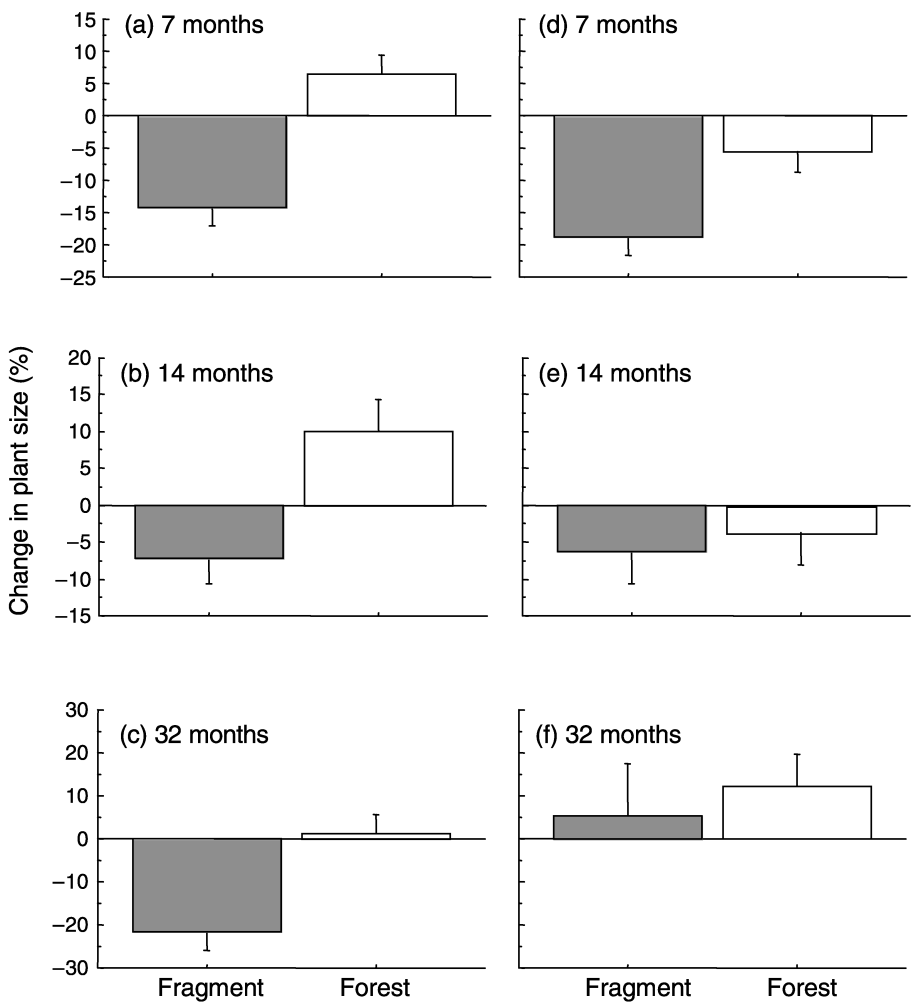

Fig. 3 Mean change in leaf area and shoots $( \pm 1 \mathrm{SE})$ 7, 14 and 32 months after transplanting to continuous forest (open bars) and forest fragments (filled bars).

Table 2 Results of a multivariate analysis of variance on the proportional change in leaf area and shoot number 32 months after transplanting at increasing distances from fragment edges

\begin{tabular}{|c|c|c|c|c|}
\hline Source of variation & Wilks’ $\Lambda$ & d.f. & $F$ & $P$ \\
\hline Distance from edge & 0.873 & 6,250 & 2.926 & 0.009 \\
\hline Source habitat & 0.989 & 2,125 & 0.690 & 0.503 \\
\hline Site & 0.892 & 6,250 & 2.447 & 0.026 \\
\hline Site $\times$ Source habitat & 0.943 & 6,250 & 1.249 & 0.282 \\
\hline Site $\times$ Distance from edge & 0.919 & 18,254 & 0.919 & 0.556 \\
\hline Source habitat $\times$ Distance from edge & 0.967 & 6,254 & 0.703 & 0.647 \\
\hline Distance from edge $\times$ Site $\times$ Source habitat & 0.898 & 18,254 & 0.765 & 0.740 \\
\hline
\end{tabular}

(C) 2002 British Ecological Society, Journal of Ecology, 90, 639-649
SE, Fig. 3f). While the strength of these responses varied across sites $(P<0.0001)$, the source habitat did not significantly affect growth rates, either as a main effect or in any interaction terms (Table 1).

Thirty-two months after transplanting there were significant differences between the growth rates of plants at different distances from fragment edges $(P=0.009$, Table 2$)$. Plants on edges were significantly larger than plants at almost all other distances and, on average, these were the only plants in fragments that increased in size (Fig. 4c,f). Growth rates were not, however, consistent among fragments (site main effect, $P=0.026$, Table 2) and, although there was no significant site-distance interaction, growth rates were positive on the edges of two of the fragments (FF-3 and
FF-4) and negative on the borders of the other two (FF-1 and FF-2).

Final $H$. acuminata root biomass ranged from 0.01 to $24.06 \mathrm{~g}$ in continuous forest $($ mean $=5.75 \pm 0.34 \mathrm{SE})$ and from 0.12 to $76.92 \mathrm{~g}$ in forest fragments (mean = $8.35 \pm 0.88 \mathrm{SE}$ ). There was a significant main effect of destination habitat on final $\mathrm{R}: \mathrm{S}$ ratio $\left(F_{1,268}=4.251\right.$, $P=0.04)$, with a mean final $\mathrm{R}: \mathrm{S}$ ratio of $1.57 \pm 0.16$ $\mathrm{SE}$ for plants transplanted to forest fragments vs. $1.19 \pm 0.11 \mathrm{SE}$ for those transplanted to continuous forest. There was no significant main effect of source habitat or site, although there was a significant site $\times \ln$ (final biomass) interaction (Table 3 ). Results of Tukey tests indicated that plants at site 2 had significantly higher $\mathrm{R}: \mathrm{S}$ ratios than plants at the other 

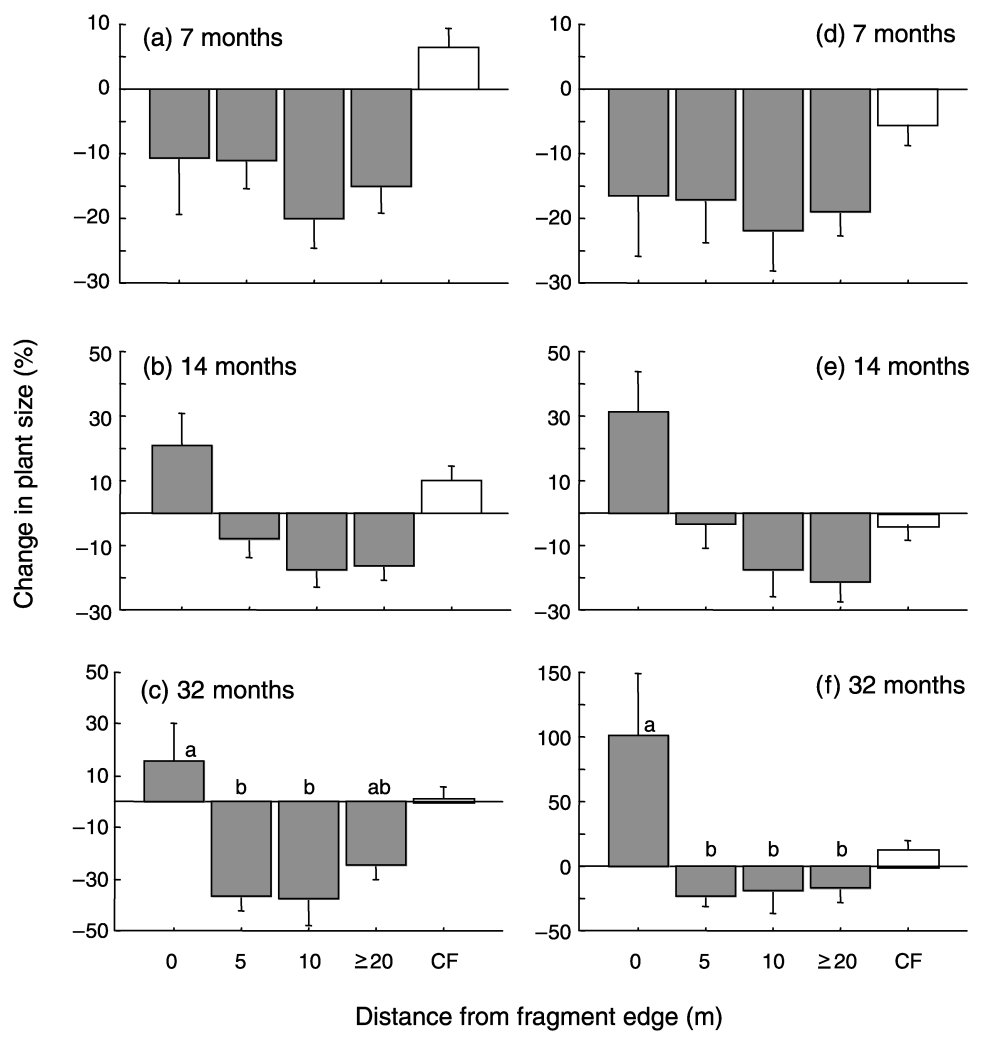

Fig. 4 Mean change in leaf area and shoots $( \pm 1 \mathrm{SE}) 7,14$ and 32 months after transplanting at increasing distances from fragment edges. For overall values, different letters indicate significant differences $(P<0.05)$ between means on the basis of Tukey posthoc tests. The mean change for plants in continuous forest $(\mathrm{CF})$ is shown for comparison but was not included in statistical analyses. Note the different scales in $4 \mathrm{c}$ and $4 \mathrm{f}$.

Table 3 Results of an analysis of covariance on the ratio of root biomass to shoot biomass 32 months after reciprocally transplanting $H$. acuminata individuals between continuous forest and forest fragments

\begin{tabular}{lcccc}
\hline Source of variation & d.f. & SS & $F$ ratio & $P$ \\
\hline Destination habitat type & 1 & 1.979 & 4.251 & 0.040 \\
Site & 3 & 2.348 & 1.682 & 0.171 \\
Source habitat type & 1 & 0.129 & 0.278 & 0.600 \\
Ln(final biomass) & 1 & 9.359 & 20.108 & $<0.0001$ \\
Destination habitat $\times$ Site & 3 & 1.523 & 1.091 & 0.353 \\
Destination habitat $\times$ Source habitat & 1 & 0.211 & 0.453 & 0.501 \\
Destination $\times$ Ln $($ final biomass) & 1 & 1.517 & 3.260 & 0.072 \\
Site $\times$ Source habitat & 3 & 2.492 & 1.785 & 0.150 \\
Site $\times$ Ln(final biomass) & 3 & 6.779 & 4.855 & 0.003 \\
Source habitat type $\times$ Ln(final biomass) & 1 & 0.172 & 0.369 & 0.544 \\
Destination habitat $\times$ Site $\times$ Source habitat & 3 & 2.513 & 1.8 & 0.148 \\
Destination habitat $\times$ Site $\times$ Ln(final biomass) & 3 & 0.56 & 0.401 & 0.752 \\
Source habitat $\times$ Source $\times$ Ln(final biomass) & 3 & 1.586 & 1.136 & 0.335 \\
Destination $\times$ Source $\times$ Ln(final biomass) & 1 & 0.009 & 0.02 & 0.888 \\
Destination $\times$ Site $\times$ Source $\times$ Ln(final biomass) & 3 & 2.934 & 2.101 & 0.100 \\
Residual & 268 & 124.733 & & \\
\hline
\end{tabular}

(C) 2002 British

Ecological Society, Journal of Ecology, 90, 639-649 three sites, despite having the lowest biomass of all locations.

In forest fragments the $\mathrm{R}: \mathrm{S}$ ratios varied significantly with edge proximity $(P=0.015)$, although not with site or source habitat (Table 4). Tukey tests were unable to detect differences in mean $\mathrm{R}: \mathrm{S}$ ratio between any pairs of edge distances, possibly due to the lower power of multiple-comparison tests relative to A NOVA (Zar 1999). However, visual inspection indicates that $\mathrm{R}: \mathrm{S}$ ratios were lower $5 \mathrm{~m}$ from the edges than at other distances (Fig. 5).

The soils in the BDFFP study area are generally poor, with high levels of aluminium, a paucity of organic material, limited macro- and micronutrients, 
Plant growth in rain forest fragments

Table 4 Results of an analysis of covariance on the ratio of root biomass to shoot biomass 32 months after transplanting $H$. acuminata individuals at increasing distances from fragment edges

\begin{tabular}{|c|c|c|c|c|}
\hline Source of variation & d.f. & SS & $F$ ratio & $P$ \\
\hline Distance from the edge & 3 & 4.848 & 3.663 & 0.015 \\
\hline Site & 3 & 1.493 & 1.128 & 0.342 \\
\hline Source habitat type & 1 & 0.087 & 0.196 & 0.659 \\
\hline Ln(final biomass) & 1 & 8.0858 & 18.263 & $<0.0001$ \\
\hline Distance from the edge $\times$ Site & 9 & 5.468 & 0.608 & 0.211 \\
\hline Distance from the edge $\times$ Source habitat & 3 & 0.283 & 0.214 & 0.887 \\
\hline Distance from the edge $\times \operatorname{Ln}$ (final biomass) & 3 & 3.526 & 2.664 & 0.053 \\
\hline Site $\times$ Source habitat & 3 & 1.099 & 0.830 & 0.481 \\
\hline Site $\times$ Ln(final biomass) & 3 & 1.672 & 1.263 & 0.292 \\
\hline Source habitat type × Ln(final biomass) & 1 & 0.145 & 0.328 & 0.569 \\
\hline Distance from the edge $\times$ Site $\times$ Source habitat & 9 & 3.171 & 0.799 & 0.619 \\
\hline Distance from edge $\times$ Site $\times$ Ln(final biomass $)$ & 9 & 4.843 & 1.220 & 0.294 \\
\hline Source habitat $\times$ Source $\times \operatorname{Ln}($ final biomass $)$ & 3 & 0.851 & 0.643 & 0.589 \\
\hline Distance from edge $\times$ Source $\times$ Ln(final biomass $)$ & 3 & 0.400 & 0.302 & 0.824 \\
\hline Distance $\times$ Site $\times$ Source $\times$ Ln(final biomass $)$ & 9 & 2.749 & 0.692 & 0.714 \\
\hline Residual & 87 & 38.384 & & \\
\hline
\end{tabular}

Table 5 Soil chemistry parameters in continuous forest and forest fragments, and results of Mann-Whitney $U$-test comparisons (Bonferroni adjusted $\alpha$ value required for significance, $P=0.004$ )

\begin{tabular}{|c|c|c|c|c|}
\hline Variable & $\begin{array}{l}\text { Continuous forest } \\
(\text { Mean } \pm \mathrm{SE})\end{array}$ & $\begin{array}{l}\text { Forest fragments } \\
(\text { Mean } \pm \text { SE) }\end{array}$ & $U$ & $P$-value \\
\hline $\mathrm{pH}$ in water & $3.78 \pm 0.105$ & $3.68 \pm 0.034$ & 8.0 & 0.48 \\
\hline $\mathrm{Ca}^{2+}$ (m.e. $100 \mathrm{~g}^{-1}$ dry soils) & $0.076 \pm 0.024$ & $0.086 \pm 0.017$ & 6.0 & 0.99 \\
\hline $\mathrm{Cu}\left(\mathrm{mg} \mathrm{kg}^{-1}\right)$ & $0.135 \pm 0.028$ & $0.146 \pm 0.025$ & 7.0 & 0.72 \\
\hline $\mathrm{Fe}\left(\mathrm{mg} \mathrm{kg}^{-1}\right)$ & $254.017 \pm 15.058$ & $218.095 \pm 23.409$ & 10.0 & 0.16 \\
\hline $\mathrm{Mn}^{2+}\left(\mathrm{mg} \mathrm{kg}^{-1}\right)$ & $1.727 \pm 0.812$ & $1.878 \pm 0.352$ & 7.0 & 0.72 \\
\hline $\mathrm{Zn}^{+}\left(\mathrm{mg} \mathrm{kg}^{-1}\right)$ & $0.544 \pm 0.085$ & $0.721 \pm 0.09$ & 10.0 & 0.16 \\
\hline $\mathrm{Mg}^{2+}$ (m.e. $100 \mathrm{~g}^{-1}$ dry soils) & $0.1 \pm 0.034$ & $0.139 \pm 0.031$ & 7.0 & 0.72 \\
\hline $\mathrm{K}^{+}\left(\mathrm{mg} \mathrm{kg}^{-1}\right)$ & $18.794 \pm 2.807$ & $24.067 \pm 3.241$ & 8.0 & 0.48 \\
\hline $\mathrm{Al}^{3+}$ (m.e. $100 \mathrm{~g}^{-1}$ dry soils) & $1.728 \pm 0.263$ & $1.929 \pm 0.095$ & 7.0 & 0.72 \\
\hline Total $\mathrm{P}\left(\mathrm{mg} \mathrm{kg}^{-1}\right)$ & $1.067 \pm 0.067$ & $1.278 \pm 0.137$ & 9.0 & 0.27 \\
\hline $\mathrm{C}\left(\mathrm{g} \mathrm{kg}^{-1}\right)$ & $19.63 \pm 4.097$ & $24.652 \pm 2.246$ & 10.0 & 0.16 \\
\hline Total org. material $\left(\mathrm{g} \mathrm{kg}^{-1}\right)$ & $33.763 \pm 7.048$ & $42.401 \pm 3.863$ & 10.0 & 0.16 \\
\hline
\end{tabular}

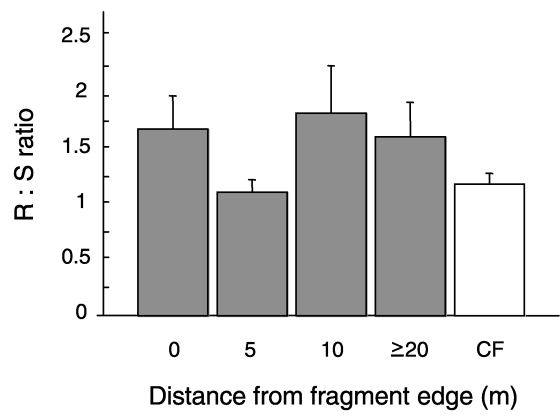

Fig. 5 The mean ratio of root biomass to shoot biomass $(\mathrm{R}: \mathrm{S}$ ratio $\pm 1 \mathrm{SE}) 32$ months after plants were transplanted to continuous forest (open bars) or fragments (filled bars). The CF value is included only for comparison.

and extremely low $\mathrm{pH}$ (Table 5). No significant differences were found, however, between continuous forest and fragments for any of the 12 soil attributes measured (Table 5).

The number of plants predicted to flower in continuous forest increased from 15 to $17(+13 \%)$, while the number in fragments decreased from 11 to $7(-36 \%)$. This difference was marginally significant $\left(\chi^{2}=3.61\right.$, $\left.\chi_{0.05,1}^{2}=3.841,0.10<P<0.05\right)$.

\section{Discussion}

The shedding of shoots and leaves, which limits water loss by reducing surface area (Begg 1980), is a common response by many tropical plants to water and temperature stress (Wright 1996; Rundel et al. 1998). By the end of the 2001 dry season, plants transplanted to forest fragments had lost $20 \%$ of their vegetative shoots, while those in continuous forest had grown slightly (Fig. 3c). Plants in continuous forest also increased in leaf area twice as much as plants in forest fragments (Fig. 3f). These long-term results are consistent with patterns observed during earlier measurements. Although there was considerable growth by plants in both fragments and continuous forest during the second rainy season (Fig. 3b,e), plants in fragments never recovered from initial dry season losses of leaf
Journal of Ecolog, 90, 639-649 
646

E. M. Bruna et al. area and shoots (Fig. 3a,d). The asymmetrical losses of leaf area and shoots during the dry seasons, as well as final differences in growth rates, suggest that the normal abiotic stresses to which these understorey plants are exposed are greatly exacerbated in forest fragments.

Previous studies conducted in the BDFFP reserves including the reserves used in this study - have demonstrated that fragments are hotter and drier than continuous forest. Ambient temperatures in fragments and forest edges, for example, can be up to $8^{\circ} \mathrm{C}$ higher than in forest interiors (Kapos 1989; Didham \& Lawton 1999). Fragments are also exposed to increased wind turbulence (Miller et al. 1991; Laurance et al. 1998), which, in combination with elevated temperatures, accelerates rates of evaporative water loss (Didham \& Lawton 1999) and reduces relative humidity. While the precise physiological mechanism responsible for leaf shedding by $H$. acuminata is unclear, it is likely that both higher temperatures and reduced humidity contribute to the disparities in growth rates. Both can cause increased evapotranspiration, reductions in turgor pressure, and leaf wilt (Dias-Filho \& Dawson 1995). We often found dried leaves attached to plants in fragments a full 32 months after the transplants were conducted.

A recent study comparing patterns of wet- and dry-season vegetative growth in Heliconia and other understorey monocots indicates they are relatively intolerant of dry-season water stress (Skillman et al. 1999). Fragmentation-related differences in soil moisture may therefore be an additional mechanism responsible for reduced growth in fragments. Soil moisture in the BDFFP fragments is lower than in control areas (Kapos 1989; Kapos et al. 1997), and it can be substantially depleted at distances up to 20-40 m from a fragment edge (Kapos 1989; Kapos et al. 1997). Furthermore the soils in our study sites are heavily weathered ferralsols, which in addition to being acidic and bereft of nutrients have poor water-retention capacity (Chauvel et al. 1987; Laurance et al. 1999). As understorey Heliconia have very shallow root systems (Skillman et al. 1999, E. M. Bruna, personal observation), it is likely that water stress in fragments is particularly acute (Wright et al. 1992).

In addition to the overall negative effect of fragmentation on $H$. acuminata growth, the significant effect of 'site' indicates there was considerable heterogeneity in growth rates among fragments (Tables 1 and 2). Intersite variability in demographic parameters is not unexpected, particularly in tropical systems (e.g. Horvitz \& Schemske 1995). In addition to variability in soil chemistry (Laurance et al. 1999; this study) and initial forest structure (Rankin-de Mérona et al. 1992), each fragment has also had a unique isolation history (BDFFP records). Furthermore, the landscape in which fragments are embedded contains several different kinds of regenerating forest (Mesquita et al. 2001), and the structure of this regrowth has previously been shown to influence plants surviving in fragments (Mesquita et al. 1999). All of these factors could potentially be driving the observed interfragment differences in growth rates. However, it is worth noting that no logging or other form of anthropogenic disturbance that might increase canopy openness, and therefore exacerbate abiotic changes, is permitted in the BDFFP fragments. This suggests that the reductions in plant growth we describe might actually be highly conservative when compared with those of plants in 'natural' forest fragments.

Plants can be phenotypically plastic in their responses to stress and acclimate physiologically to altered environmental conditions over time (Turner \& Kramer 1980). However, the lack of any significant effects of source habitat on growth rates (Tables 1 and 2) might indicate that there was no pre-transplant response to conditions in forest fragments. Alternatively, optimality theory predicts that, when exposed to more xeric conditions, plants should shift resources from aboveground tissue to the production of roots in rhizomes in order to enhance the uptake of water from the soil (Struik \& Bray 1970; Bloom et al. 1985). Plants in high light environments would be expected to respond similarly, as light is no longer limiting carbon fixation (McConnaughay \& Coleman 1999). Given the reduced soil moisture and increased sunlight in fragments, one might predict that $H$. acuminata transplanted to fragments should have higher $\mathrm{R}: \mathrm{S}$ ratios than those transplanted to continuous forest.

The results of our experiment are consistent with this prediction, as both below-ground biomass and $\mathrm{R}: \mathrm{S}$ ratios are higher in forest fragments. However, several caveats require that these results be interpreted cautiously. First, the proportion of below-ground biomass could have increased in part because above-ground tissue was lost. This would give the appearance of active shifts in resource allocation, without actually resulting from a change in allocation strategy. Secondly, $\mathrm{R}$ : $\mathrm{S}$ ratios are negatively correlated with plant size (McConnaughay \& Coleman 1999) and, as plants in continuous forest grew more than those in forest fragments, they might a priori be expected to have lower $\mathrm{R}$ : S ratios. Thirdly, plants on the borders of fragments should have the largest $\mathrm{R}: \mathrm{S}$ ratios of all, as edges have the highest levels of solar radiation and lowest soil moisture levels. This is not the case, however, with R: S ratios similar on fragment borders and in fragment interiors (Fig. 5). Finally, if plants in fragments are in fact reallocating resources in response to abiotic conditions, then those individuals collected and replanted in the same forest fragments should have already shifted biomass prior to the start of the experiment. The lack of any significant main or interaction effects of 'source habitat', however, strongly suggests there had been no local pre-transplant response by plants. Careful experiments are needed to discriminate among these hypotheses; nevertheless, our results provide tantalizing evidence that plants in forest fragments may shift biomass to below-ground storage structures in response to altered abiotic conditions. Because root size and thus the ability to extract water from drying
Ecological Society, Journal of Ecology, 90, 639-649 
Plant growth in rain

forest fragments soil can influence survival after rain forest disturbance (Lovelock et al. 1994), this could be an important mechanism promoting plant persistence in habitat fragments.

Perhaps the most unexpected result of our study was the rapid and substantial growth by plants on fragment edges. While initial dry-season losses in these locations were comparable with those at other distances from the edge (Fig. 4a,d), these plants rebounded extremely quickly during the following rainy season (Fig. 4b,e). By 32 months after transplanting their rate of growth far outpaced not only that of other plants in fragments, but also that of plants in continuous forest sites (Fig. 4c,f). These results were not consistent across locations, however. Plants on the edges of two fragments responded favourably to edge proximity (FF-3, FF-4), while those on the edges of the other two responded negatively (FF-1, FF-2). The mechanisms responsible for these idiosyncratic growth rates on edges are unclear. Increased solar radiation on edges is one likely causal factor, but, as plants regenerated quickly on the edges of only two fragments, it is probably only partially responsible. Microscale variation in soil chemistry, which was not significantly different among sites at the coarse scale at which we measured it, is probably also playing a role. It is worth noting that the newly flushed leaves of plants on fragment edges, including rapidly growing ones, had the characteristic yellowing indicative in Heliconia of solar damage to the photosynthetic system (He et al. 1996). In shade-tolerant species photoinhibition can increase susceptibility to drought and other forms of stress, and it may ultimately promote leaf death and abscission (Gamon \& Pearcy 1990; Lovelock et al. 1994; Lovelock et al. 1998). As such, the increases in leaf area and shoot numbers seen in some 'edge' plants may not correspond to increases in photosynthetic capacity or overall plant health.

Changes in shoot number may be particularly critical demographically (Bruna 2001). Plants in fragments failed to recuperate fully from initial dry season losses before the onset of subsequent dry season (Fig. 3b), and these losses continued during the following year of the experiment (Fig. 3c). The compounding loss of shoots over the course of multiple dry seasons could explain why the $H$. acuminata populations in habitat fragments are more skewed towards smaller demographic size classes than those in continuous forest (Bruna \& Kress 2002). Furthermore, while the predicted shifts in the abundance of flowering H. acuminata in fragments and continuous forest were only marginally significant, they closely mirror the disparities documented in permanent demographic plots (Bruna \& Kress 2002). Previous efforts to quantify the consequences of fragmentation for plant reproduction have focused almost entirely on changes in plantanimal interactions, particularly pollination and seed predation (Aizen \& Feinsinger 1994; Jules \& Rathcke 1999; Cunningham 2000; Dick 2001). Our results suggest a new way that plant fitness can be reduced in fragments: indirectly, via environmentally induced changes in plant size and population structure.

We took a novel, experimental approach to show that organismal growth rates can be altered in habitat fragments. As suggested by a number of previous correlative studies, these physiological changes are probably the result of the striking changes in abiotic conditions associated with the fragment isolation and edge creation. We suggest that fragmentation-related reductions in growth rates could have important demographic consequences for understorey plants, as they could drive alterations in population structures and the reduced abundance of reproductive plants. If severe enough, environmentally induced changes in plant size may help explain why populations of plants in habitat fragments often fail to persist over the long-term (Turner et al. 1994; Jules 1998), particularly if reductions in flowering act in concert with fragmentationrelated changes in other stages of plant reproduction (Aizen \& Feinsinger 1994; Bruna 1999; Jules \& Rathcke 1999; Ortiz-Pulido et al. 2000). Finally, the results of this study provide additional evidence that even geographically widespread or abundant species can be detrimentally affected by the environmental changes associated with fragmentation (Stratford \& Stouffer 2001; Bruna \& Kress 2002). This further underscores the importance of implementing conservation strategies that reduce abiotic edge effects, such as the use of buffer zones and the active management of habitat surrounding fragments (Gascon et al. 2000), as edge effects may substantially influence the growth and reproduction of remnant populations in previously unexpected ways.

\section{Acknowledgements}

We thank F. Marques, O. F. da Silva and J. Ribamar for assistance in the field and J. Hoeksema, M. Stanton, K. Rice, J. Thaler, W. Laurance, P. Delamônica, J. Umbanhowar, M. Allen, A. Agrawal, H. Vasconcelos, B. Inouye, J. Wright, L. Haddon, K. Clay and three anonymous reviewers for helpful discussions or comments on the manuscript. We would also like to thank the BDFFP for providing logistical support and the Manaus Free Trade Zone Authority (SUFRAMA) for permission to conduct the research. This work was supported by NSF Dissertation Improvement Grant INT 98-0635 and fellowships from UC Davis Graduate Studies, the UC Davis Center for Population Biology, the Smithsonian Graduate Student Fellowship Programme, and the NSF Minority Postdoctoral Fellowship programme. This is publication number 377 in the BDDFP technical series.

\section{References}

Aizen, M.A. \& Feinsinger, P. (1994) Forest fragmentation, pollination, and plant reproduction in a chaco dry forest, Argentina. Ecology, 75, 330-351.
Journal of Ecolo

90, 639-649 
648

E. M. Bruna et al.
Begg, J.E. (1980) Morphological adaptations of leaves to water stress. Adaptation of Plants to Water and High Temperature Stress (eds N.C. Turner \& P.J. Kramer), pp. 33-42. John Wiley and Sons, New York.

Berry, F. \& Kress, W.J. (1991) Heliconia: an Identification Guide. Smithsonian Institution Press, Washington D.C.

Berwaerts, K., Van Dyck, H., Van Dongen, S. \& Matthysen, E. (1998) Morphological and genetic variation in the speckled wood butterfly (Pararge aegeria L.) among differently fragmented landscapes. Netherlands Journal of Zoology, 48, 241-253.

Bloom, A.J., Chapin, F.S. III \& Mooney, H.A. (1985) Resource limitation in plants: an economic analogy. Annual Review of Ecology and Systematics, 16, 363-392.

Bruna, E.M. (1999) Seed germination in rainforest fragments. Nature, 402, 139.

Bruna, E.M. (2001) Effect of habitat fragmentation on the reproduction and population dynamics of an Amazonian understory herb (Heliconia acuminata, Heliconiaceae). $\mathrm{PhD}$ thesis, University of California, Davis.

Bruna, E.M. \& Kress, W.J. (2002) Habitat fragmentation and the demographic structure of an Amazonian understory herb (Heliconia acuminata). Conservation Biology, in press.

Camargo, J.L.C. \& Kapos, V. (1995) Complex edge effects on soil moisture and microclimate in central Amazonian forest. Journal of Tropical Ecology, 11, 205-221.

Carvalho, K.S. \& Vasconcelos, H.L. (1999) Forest fragmentation in central Amazonia and its effect on litter-dwelling ants. Biological Conservation, 91, 151-158.

Chauvel, A., Lucas, Y. \& Boulet, R. (1987) On the genesis of the soil mantle of the region of Manaus, Central Amazonia, Brazil. Experientia, 43, 234-241.

Chen, J., Franklin, J.F. \& Spies, T.A. (1992) Vegetation responses to edge environments in old-growth Douglas Fir forest. Ecological Applications, 2, 387-396.

Cunningham, S.A. (2000) Depressed pollination in habitat fragments causes low fruit set. Proceedings of the Royal Society Biological Sciences Series B, 267, 1149-1152.

Dias-Filho, M.B. \& Dawson, T.E. (1995) Physiological responses to moisture stress in two Amazonian gap-invader species. Functional Ecology, 9, 213-221.

Dick, C.W. (2001) Genetic rescue of remnant tropical trees by an alien pollinator. Proceedings of the Royal Society Biological Sciences Series B, 268, 2391-2396.

Didham, R.K., Hammond, P.M., Lawton, J.H., Eggleton, P. \& Stork, N.E. (1998) Beetle species responses to tropical forest fragmentation. Ecological Monographs, 68, 295-323.

Didham, R.K. \& Lawton, J.H. (1999) Edge structure determines the magnitude of changes in microclimate and vegetation structure in tropical forest fragments. Biotropica, 31, 17-30.

EMBRAPA (1997) Manual de Métodos de Análise de Solo, $2 a$ Edição. Produção de Informação-EMBRAPA, Rio de Janeiro, Brazil.

Gamon, J.A. \& Pearcy, R.W. (1990) Photoinhibition in Vitis californica: interactive effects of sunlight, temperature and water status. Plant Cell and Environment, 13, $267-$ 276.

Gascon, C., Williamson, G.B. \& da Fonseca, G.A.B. (2000) Receding forest edges and vanishing reserves. Science, 288, $1356-1358$.

Gehlhausen, S.M., Schwartz, M.W. \& Augspurger, C.K. (2000) Vegetation and microclimatic edge effects in two mixed-mesophytic forest fragments. Plant Ecology, 147, 21-35.

Harper, J.L. (1977) Population Biology of Plants. Academic Press, New York.

(C) 2002 British Ecological Society, Journal of Ecology, 90, 639-649

Harrison, S. \& Bruna, E. (1999) Habitat fragmentation and large-scale conservation: what do we know for sure? Ecography, 22, 225-232.
He, J., Chee, C.W. \& Goh, C.J. (1996) 'Photoinhibition' of Heliconia under natural tropical conditions: the importance of leaf orientation for light interception and leaf temperature. Plant Cell and Environment, 19, 1238-1248.

Horvitz, C.C. \& Schemske, D.W. (1995) Spatiotemporal variation in demographic transitions of a tropical understory herb: projection matrix analysis. Ecological Monographs, 65, 155-192.

Jules, E.S. (1998) Habitat fragmentation and demographic change for a common plant: Trillium in old-growth forest. Ecology, 79, 1645-1656.

Jules, E.S. \& Rathcke, B.J. (1999) Mechanisms of reduced Trillium recruitment along edges of old-growth forest fragments. Conservation Biology, 13, 784-793.

Kapos, V. (1989) Effects of isolation on the water status of forest patches in the Brazilian Amazon. Journal of Tropical Ecology, 5, 173-185.

Kapos, V., Wandelli, E., Camargo, J.L. \& Ganade, G. (1997) Edge-related changes in environment and plant responses due to forest fragmentation in Central Amazonia. Tropical Forest Remnants: Ecology, Management, and Conservation of Fragmented Communities (eds W.F. Laurance \& R.O. Bierregaard Jr), pp. 33-44. University of Chicago Press, Chicago.

Laurance, W.F. \& Bierregaard, R.O. (1997) Tropical Forest Remnants: Ecology, Management, and Conservation of Fragmented Communities. University of Chicago Press, Chicago.

Laurance, W.F., Fearnside, P.M., Laurance, S.G., Delamonica, P., Lovejoy, T.E., Rankin de Merona, J.M., Chambers, J.Q. \& Gascon, C. (1999) Relationship between soils and Amazon forest biomass: a landscape-scale study. Forest Ecology and Management, 118, 127-138.

Laurance, W.F., Ferreira, L.V., Rankin de Merona, J.M. \& Laurance, S.G. (1998) Rain forest fragmentation and the dynamics of Amazonian tree communities. Ecology, 79, 2032-2040.

Leach, M.K. \& Givnish, T.J. (1996) Ecological determinants of species loss in remnant prairies. Science, 273, 1555-1558.

Lovejoy, T.E., Bierregaard, R.O., Rylands, A.B., Malcolm, J.R., Quintela, C.E., Harper, L.H., Brown, K.S., Powell, A.H., Powell, C.V.N., Schubart, H.O.R. \& Hays, M.B. (1986) Edge and other effects of isolation on Amazon forest fragments. Conservation Biology: the Science of Scarcity and Diversity (ed. M. Soulé), pp. 257-285. Sinauer and Associates, Sunderland, Massachusetts.

Lovelock, C.E., Jebb, M. \& Osmond, C.B. (1994) Photoinhibition and recovery in tropical plant species: response to disturbance. Oecologia, 97, 297-307.

Lovelock, C.E., Kursar, T.A., Skillman, J.B. \& Winter, K. (1998) Photoinhibition in tropical forest understorey species with short- and long-lived leaves. Functional Ecology, 12, 553-560.

McConnaughay, K.D.M. \& Coleman, J.S. (1999) Biomass allocation in plants: ontogeny or optimality? A test along three resource gradients. Ecology, 80, 2581-2593.

Mesquita, R., Delamonica, P. \& Laurance, W.F. (1999) Effect of surrounding vegetation on edge-related tree mortality in Amazonian forest fragments. Biological Conservation, 91, 129-134.

Mesquita, R.C.G., Ickes, K., Ganade, G. \& Williamson, G.B. (2001) Alternative successional pathways in the Amazon Basin. Journal of Ecology, 89, 528-537.

Miller, D.R., Lin, J.D. \& Lu, Z.N. (1991) Some effects of surrounding forest canopy architecture on the wind field in small clearing. Forest Ecology and Management, 45, 7992.
Ortiz-Pulido, R., Laborde, J. \& Guevara, S. (2000) Fruiteating habits of birds in a fragmented landscape: implications for seed dispersal. Biotropica, 32, 473-488. 
649

Plant growth in rain

forest fragments
Rankin-de Mérona, J.M., Prance, G.T., Hutchings, R.W., Silva, F.M., Rodrigues, W.A. \& Uehling, M.E. (1992) Preliminary results of large scale tree inventory of upland rain forest in the central Amazon. Acta Amazonica, 22, 493-534.

Rundel, P.W., Sharifi, M.R., Gibson, A.C. \& Esler, K.J. (1998) Structural and physiological adaptation to light environments of neotropical Heliconia (Heliconiaceae). Journal of Tropical Ecology, 14, 789-801.

Skillman, J.B., Garcia, M. \& Winter, K. (1999) Whole-plant consequences of Crassulacean acid metabolism for a tropical forest understory plant. Ecology, 80, 1584-1593.

Stratford, J.A. \& Stouffer, P.C. (2001) Reduced feather growth rates of two common birds inhabiting central Amazonian forest fragments. Conservation Biology, 15, 721-728.

Strong, D.R. (1977) Rolled-leaf Hispine beetles (Chrysomelidae) and their Zingiberales host plants in Middle America. Biotropica, 9, 156-169.

Struik, G.J. \& Bray, J.R. (1970) Root-shoot ratios on native forest herbs and Zea mays at different soil moisture levels. Ecology, 51, 892-893.

Sumner, J., Moritz, C. \& Shine, R. (1999) Shrinking forest shrinks skink: morphological change in response to rainforest fragmentation in the prickly forest skink (Gnypetoscincus queenslandiae). Biological Conservation, 91, 159-167.
Turner, N.C. \& Kramer, P.J. (1980) Adaptation of Plants to Water and High Temperature Stress. Wiley, New York.

Turner, I.M., Tan, H.T.W., Wee, Y.C., Ibrahim, A.B., Chew, P.T. \& Corlett, R.T. (1994) A study of plant species extinction in Singapore: lessons of the conservation of tropical biodiversity. Conservation Biology, 8, 705-712.

Weishampel, J.F., Shugart, H.H. \& Westman, W.E. (1997) Phenetic variation in insular populations of a rainforest centipede. Tropical Forest Remnants: Ecology, Management, and Conservation of Fragmented Communities, pp. 111-123. (eds W.F. Laurance \& R.O. Bierregaard Jr) University of Chicago Press, Chicago.

Wright, S.J. (1996) Phenological responses to seasonality in tropical forest plants. Tropical Forest Plant Ecophysiology (eds S.S. Mulkey, R.L. Chazdon \& A.P. Smith), pp. 440 460. Chapman \& Hall, New York.

Wright, S.J., Machado, J.L., Mulkey, S.S. \& Smith, A.P. (1992) Drought acclimation among tropical forest shrubs (Psychotria, Rubiaceae). Oecologia, 89, 457-463.

Zar, J.H. (1999) Biostatistical Analysis. Prentice Hall, Upper Saddle River, New Jersey.

Received 17 January 2002

revision accepted 18 March 2002
(C) 2002 British

Ecological Society, Journal of Ecology,

90, 639-649 